C 112

\title{
カラ一デフォーカス法の性能向上と検討
}

\author{
山内 俊典 ${ }^{\circ}$ (関西大学大学院)，山本 共史 (関西大学), \\ 井口学(北海道大学), 椤村 知正 (関西大学)
}

\section{Improvement and consideration of color defocus method}

\author{
Toshinori Yamauchi, Yasufumi Yamamoto, Manabu Iguchi and Tomomasa Uemura
}

\begin{abstract}
By adding a color'scparation technique to the conventional defocus method, the capability and performance of the method can be expanded. The new method named colordefocus method can process much dense particle clistribution and its the depth of measurable area is expanded about twice. This pajer deals with further improvements of the color-defocus method. They consists of two points, one is the method to reduce the light absorption by colorffilters, and the other is the utilization of colored light, laser for example, illumination.

The conventional color defocus method uses a three-pinholes aperture mask with RGB filters, and white light illumination. In order to obtain clearer particle images, light-color filters and color separation technique are introduced. And the color separation technique enables introduction of various color filters other than RGB filters. This approach easily leads to realization of colored illumination that enables the PTV using fluorescent particles and laser illuminations.
\end{abstract}

Keywords: defocus method, HSV, 3D·PTV, color filter, reduced absorption

\section{1.はじめに}

カラーーデフォーカス法注粒子像のボケを利用して単眼

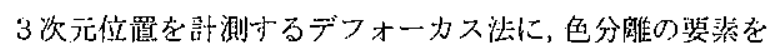
加え，铍題であった粒子像の重複を解決する方法である。 1)

Weiら゙仗本破究と同じ力ラーフィルタを解い，粒子を 白い均一背昙光で照明する条件で粒子の影を撮影して，微

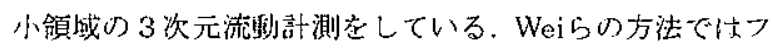
イルタや照明条件を変えると粒子像老分離できないのに 刘して, 本論文の方法は程々のフィル夕と照明条件の組み 全わせで多様な計测条件に刘忍できる。

本稿では, カラーデフォーカス法発屌させてフィル夕に 5万光の诚衰を緩和与万方法と非白色光の照明を用いる 方法について述べる。

\section{2. カラーデフォーカス法}

Fig. 1はカラーデフォーカス视による粒子の光軸位踪と

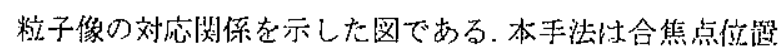
にある粒子法ボケが䎸く，一つの精子像として結像される

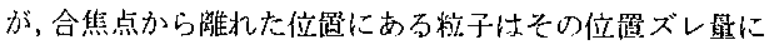
忍じた角形が観察されること老利用し，光俥方向り位箈 計測を可能にナる.カラーデフォーカス法に閔なる詳しい 説明は文献1)を参照されたい。

従来のデフォーカス法と比べて，力ラーーデフォーカス法 は計測箱围を約 2 倍に拡張でき，3倍の粒子分布密度まで 適用できる。そのためFig. 2のような高密度に分析してい る粒子像に対しても計測が可能となる。

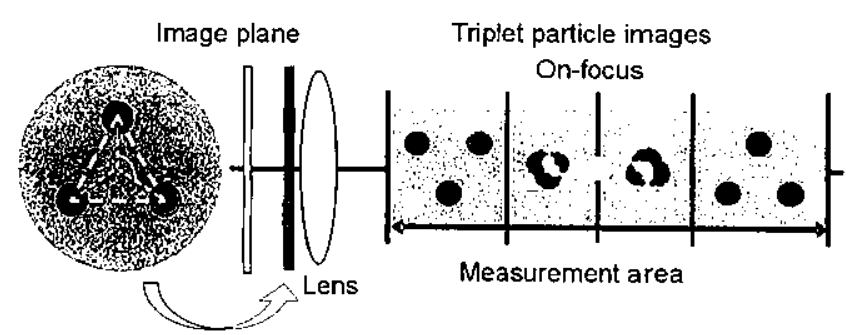

Eccentric aperture mask

Fig. 1 Triplet particle images obtained by the color defocus method. 


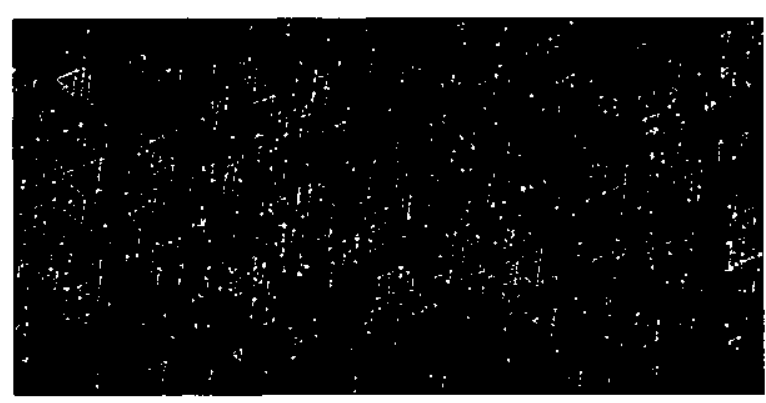

Fig.2 Triplet found in high density distribution.

\section{HSV 表現を用いた色分離法と営光粒子の利用}

前報 1で住高覃度白色光源で照明した，白色粒子苍版影 L，狄波域心 RGBフィルタ老用いて色分離した（Wei ら

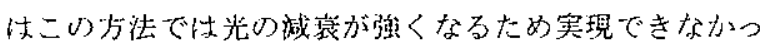
たので別法を潠んだ)，本報は減衰の少ない淡色フィルタ 学用いて撮影した画像を色分晟処理と組み合わせて光量 不足を改善与る方法と，レーザーの上うな非毛色光源で照 明する場合の処理手法について述心゙る。

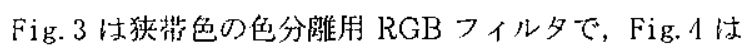
淡色 RGBフィルタで据影した粒子像である. Fig. 3 のフ イル夕は光の減衰が強いので暗い粒子像になりがちであ

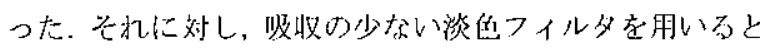
Fig.4Dように明るい粒子像が得られる。淡色フィル夕を 用いると色を完全に分離できないため他の象画面にも暗 い像が現れるが、コントラストの違いから容易に識别でき る.さらに RGB以外のフィルタを用いた場合にも HSV の色相值を考䈍す机ばどのつィルタによる粒子像かを 容易に識別できる。

Fig. 4中心数值はその粒子像部分の色相侹(deg)である.

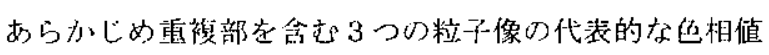
を求めて拈けば, 色潮れの大きい淡色フィル夕を用いた場 合でも粒子像㞭識别できる.Fig. 5 汢識別した絬果をRGB 画面に倠き込人で表示している。こうナると後は RGB包 分離手法を旗用できる。この手法を用い狄ば、レーザー一の 上うな色つき光で蛍光粒子を照明する場合や $R G B$ 以外心 フィルタを䐓いる場合にも粒于像学分離できる。

次にArイオンレーーザー光で橙色に発光する蛍光粒子を レーザー光と蛍光色に対応したフィルタを装着した2孔 フィルタを用いて撮影した例を示小. 蛍光粒子は蛍光色と レーザーの反射光とを発しているためFig. 6(a)，(b)の上 うな二色に分離した粒子像が得られ，これから Fig. 6(c)，(d)のように蛍光色とレーザー色に分㒕できる のでカラーデフォーカス法での計湖が可能になる。

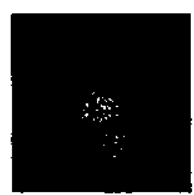

(a) original

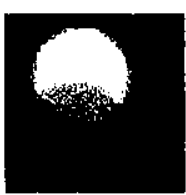

(b) red

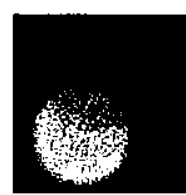

(c) green

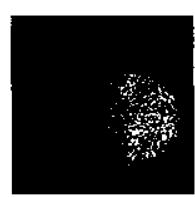

(d) blue
Fig.3 Particle images using RGB color separation filter.

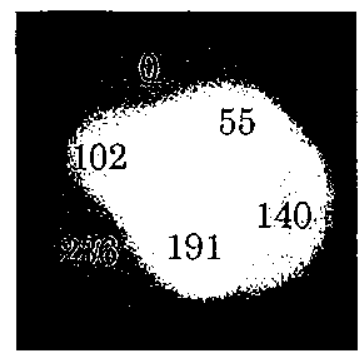

Fig.4 Particle image using light color filters.

(Hue values[deg] are shown on the picture.)

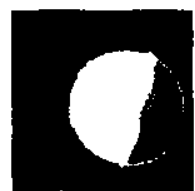

(a) processed result (b) red

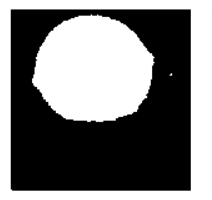

Fig. 5 Processed results from fig.

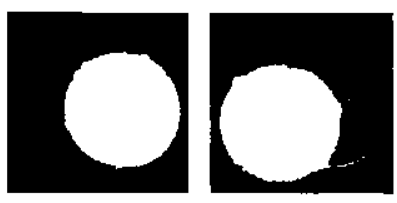

(d) blue

(c) green

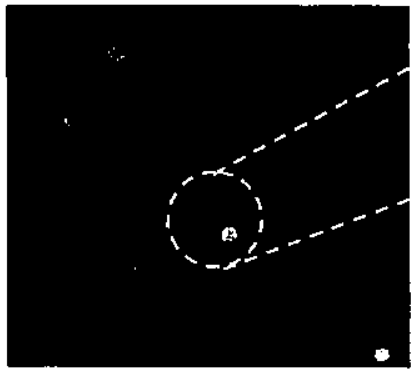

(a) original image

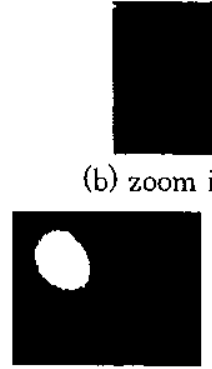

(c) red

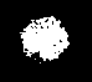

zoom image of $(a)$

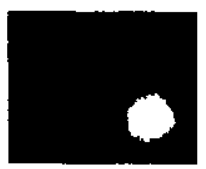

(d) green

Fig.6 Fluorescence particles illuminated by argon laser.

\section{4. 結 論}

1) 淡色フィルタを用いることで，フィルタによる光の 减哀が改善できた。

2) レーザー光源と蛍光粒子の上うな組み合吅せでも 色分離でき，粒子が抽出できることを確認した：

\section{参考文献}

1）山内俊典，山本恭史，植村知正：カラーデフォーカス法による スポット渦の3 次元流動計測, 可視化情報学会 誌, Vol. 28. Supp1. No. 1, 2008, pp. 39-42.

2) Wei-Hsin Tien, Patrick Kartes, Toru Yamasaki and Daua Dabri : A color-coded backlighted defocusing digital particle image velocimetry system, Exp Fluids, Vol. 44, (2008), pp. 1015-1026. 